\title{
Effects of Lap Configuration on Mechanical Properties and Composition Distribution of Three- layer Overlapped Laser Weldments on Al/Cu Dissimilar Materials
}

Joonghyeon Shin

Korea institute of industrial technology

Minjung Kang ( $\square$ kmj1415@kitech.re.kr)

Korea institute of industrial technology

\section{Research Article}

Keywords: Al/Cu dissimilar welding, Single-mode laser welding, Three-layer overlap welding, Tensile-shear strength, T-peel strength, Component distribution

Posted Date: January 14th, 2022

DOI: https://doi.org/10.21203/rs.3.rs-1248075/v1

License: (c) (i) This work is licensed under a Creative Commons Attribution 4.0 International License.

Read Full License 


\section{Abstract}

Battery cells are connected via bus-bars to meet performance requirements, such as power and capacity, and multiple layers of dissimilar materials functioning as anodes, cathodes, or bus-bars are overlapped and welded together. In laser welding, the formation of brittle intermetallic phases in the weld joint is inevitable and, in turn, deteriorates the mechanical properties. To obtain the desirable joint performance, appropriate welding parameters to avoid intermetallic phase formations and joint designs to release stress concentrations must be obtained. This study investigates the effects of lap configurations and process parameters on the tensile-shear load, T-peel load, and composition distribution when multilayered joints of dissimilar materials are produced by laser welding. Two layers of $0.4 \mathrm{~mm}$ Al sheets were welded with a single $0.2 \mathrm{~mm}$ Cu sheet, which was emulated using electric vehicle battery interconnects. The results show that the penetration depth varied in accordance with the lap configuration even under the same heat input condition. The lap configuration and welding parameters influenced the composition distribution of the welds, as they altered the solidification rate, number of $\mathrm{Cu} / \mathrm{Al}$ contact interfaces, and location of the high-density material. The failure load of the T-peel specimens was always lower than that of the tensile-shear specimens except for the $\mathrm{Cu}-\mathrm{Al}-\mathrm{Al}$ lap configuration. The T-peel load of the $\mathrm{Cu}-\mathrm{Al}-\mathrm{Al}$ lap configuration was similar to that of the tensile-shear load. When the stress-concentrated joint was homogeneous, it was more robust.

\section{Introduction}

Al and $\mathrm{Cu}$ are often inevitable in microelectronics and alternative energy devices, as well as in secondary batteries for hybrid vehicles and fuel cells $[1,2]$. In the battery assembly, a large number of battery cells are connected via bus-bars to meet performance requirements, such as power and capacity [3]. In such stacking configurations, multiple layers of dissimilar materials, mostly copper, nickel, or aluminum, are welded together and function either as anodes, cathodes, or bus-bars [4, 5]. Achieving consistent weld qualities and properties in the multiple-weld interfaces is critical for reliable battery assembling and electric vehicle performance [6].

However, joining dissimilar materials is challenging due to the differences in their chemical, physical, and thermal properties, such as melting temperatures, thermal diffusivities, and thermal expansion/shrinkage [6-8]. In addition, brittle intermetallic phase (IMP) formations [7] due to the chemical reaction between Al and $\mathrm{Cu}$ is inevitable, causing a decrease in the bonding strength and a low electrical conductivity $[7,9]$. The existence of thick IMPs at the joining interface causes the appearance of numerous cracks and pores [6, 10-12]. Braunovic et al. [13] reported that the deleterious effect of IMPs is reflected in the brittleness of the joint, and a higher contact resistance results based on the thickness of the IMPs formed. Lee et al. [14] reported that strong laser-welded joints could be produced at high welding speeds by suppressing the formation of intermetallic phases.

Various joining techniques involving the use of lasers [14-16], friction stir [17, 18], diffusion [19], and ultrasonic welding [20-23] have been employed in the fabrication of $\mathrm{Al}-\mathrm{Cu}$ dissimilar joints. In fusion 
welding, such as laser welding, more severe IMP formation at the dissimilar material joint results, as the melting rate of materials in this process is higher compared to other solid-state welding processes such as ultrasonic welding. Nevertheless, the laser welding technology in energy device manufacturing is expected to improve the joint quality and production efficiency by alternating between ultrasonic processes based on the advantages of high precision, high flexibility, and repeatability [24]. Studies on achieving multiple layers of Al-Cu joints using laser welding (or fusion welding) have not yet been reported. However, extensive studies have been conducted on laser-welded specimens using two material sheets. Consequently, a better understanding of the joint formation in multilayered laser-welded Al and Cu dissimilar joints is highly desired to obtain process productivities with sound joint qualities.

Minimization of IMPs can be accomplished by suppressing the intermixture of metals and reducing the processing time to avoid diffusion. Huang et al. [25] demonstrated the concentration behavior of $\mathrm{Cu}$ in a $\mathrm{Cu}$ (top)-Al (bottom) dissimilar material joint via a multi-physics numerical model and ex situ element mapping. They proved that the concentration of $\mathrm{Cu}$ in the top region of the molten pool was over $50 \mathrm{wt} \%$ under high-speed welding conditions as a result of the upward flow in the molten pool that is driven by the recoil pressure. The element mixing process in laser keyhole welding is affected by the laser power, welding speed, and heat input [25]. This indicates that proper welding parameters are required to suppress the formation of IMPs to obtain desirable joint characteristics, such as ductility and toughness.

This study investigates the effects of process parameters on the mechanical properties and composition distribution when multilayered joints of dissimilar materials are produced by laser welding. Two layers of $0.4 \mathrm{~mm}$ Al sheets were welded with a single $0.2 \mathrm{~mm}$ Cu sheet that was emulated by electric vehicle battery interconnects. Joint robustness was assessed by performing tensile-shear and T-peel tests on the specimens fabricated under various welding speed conditions. The present study attempted to evaluate the effect of lap configurations on the composition distribution and hardness and their relationships with the tensile-shear and T-peel loads.

\section{Experimental Setup}

A single-mode fiber laser (CFL-1000, Nlight, USA) was used for welding. The beam was delivered through an optical fiber with a diameter of $14 \mu \mathrm{m}$ and a two-axis scanner system (hurrySCAN30, Scanlab, Germany) with a focal length of $405.5 \mathrm{~mm}$. The beam was irradiated perpendicularly onto the specimen placed at the focal position. At the focal point, the laser beam had a beam diameter of $35.7 \mu \mathrm{m}$.

The base materials were nickel-coated C1020 (thickness: $0.2 \mathrm{~mm}$ ) and Al1050 (thickness: $0.4 \mathrm{~mm}$ ). The specimen was prepared with a width of $40 \mathrm{~mm}$ and length of $45 \mathrm{~mm}$. Fig. 1 shows the detailed geometry of the welding joint configuration for the tensile-shear and T-peel test specimens. The gap between the layers was set to $0 \mathrm{~mm}$, and the overlap length was $10 \mathrm{~mm}$. Laser overlap welding was performed with a length of $40 \mathrm{~mm}$ at the center of overlapped width, that is, at a distance of $5 \mathrm{~mm}$ away from the edge.

The laser power was maintained at $1 \mathrm{~kW}$, and the welding speed was varied from 250 to $450 \mathrm{~mm} / \mathrm{s}$ to obtain various heat input conditions. In addition, $\mathrm{Al}-\mathrm{Al}-\mathrm{Cu}(\mathrm{AAC}), \mathrm{Al}-\mathrm{Cu}-\mathrm{Al}(\mathrm{ACA})$, and $\mathrm{Cu}-\mathrm{Al}-\mathrm{Al}$ (CAA) 
three-layer lap configurations were selected to evaluate the effect of the stacking sequence on the mechanical properties and component distributions.

Tensile-shear and T-peel tests were performed on the welded length of $40 \mathrm{~mm}$, including the start and end points, to imitate the battery interconnection assembly. The joint failure load was evaluated at the interface between the second and third layers, which is a relatively narrow and weak interface due to the consumption of energy [22]. Each tensile-shear and T-peel test specimens were tested three times, and the average value was calculated.

The transverse cross-sections were polished and observed using optical microscopy and field-emission scanning electron microscopy (FE-SEM). The micro-Vickers hardness of the cross-section was measured with an indent spacing of $0.1 \mathrm{~mm}$ along the centerline of the welds. The applied load and holding time for the hardness measurements were $490 \mathrm{~N}$ and $10 \mathrm{~s}$, respectively. The chemical composition of the macrosections was analyzed via energy dispersive X-ray spectroscopy to confirm the formation of intermetallic phases.

\section{Results And Discussion}

\subsection{Effect of lap configuration on penetration depth}

The penetration depth was varied depending on the lap configuration under the same heat input conditions, as depicted in Fig. 2. As the welding speed increased, the heat input decreased, and the penetration depth tended to be shallow. At a welding speed of $350 \mathrm{~mm} / \mathrm{s}$, the penetration depth converted from full penetration to partial penetration. The reductions in penetration depth for the CAA and ACA lap configurations were greater than that for the ACC configuration. This is because when the Cu layer was placed closer to the focused laser beam, the heat input quickly dissipated to the surroundings [25] due to the high melting point and thermal diffusivity of copper. Another reason for this difference was the fact that lasers with wavelengths greater than $1 \mu \mathrm{m}$ exhibit a low absorption rate for copper [26].

The melted zone of the Cu layer was narrower than that of the Al layer due to its thermal properties, as shown in Fig. 3. All specimens had sound weld cross-sections without cracks, except under overwelded conditions. Some pores were formed near the fusion line of the Al layer. This can be explained by the turbulent melt-pool dynamics that have been reported by other researchers $[12,15]$.

\subsection{Effect of lap configuration on composition distribution}

The chemical composition distribution of the weld was affected by the lap configuration and the welding parameters. The recoil pressure induced by the laser keyhole movement stirred the molten pool, thus resulting in the mixing of components in each layer. Compositional analysis was performed on the crosssection of the welds in the middle of each layer, and the results are presented in Fig. 4 and Table 1. In the specimens with the ACA lap configuration, the Cu component was distributed throughout the fusion zone regardless of the welding speed, while for the AAC and CAA lap configuration specimens, the $\mathrm{Cu}$ 
component was concentrated near the Cu layer. For the ACA lap configuration, the Cu content reached $69.7 \%$ at a welding speed of $300 \mathrm{~mm} / \mathrm{s}$, whereas $92.3 \%$ and $83.8 \%$ of $\mathrm{Cu}$ content were measured in the AAC and CAA lap configurations, respectively. The dilution behavior and distribution of constitutional elements were altered depending on the location of the high-density Cu layer.

The composition was diluted in a relatively narrow region when the welding speed was increased to 350 $\mathrm{mm} / \mathrm{s}$ (Fig. 3). It can be predicted that the composition distribution was restricted with increasing welding speed due to the fast solidification rate.

From these results, it can be concluded that the distribution of the composition within the weld was affected by the lap configuration and welding speed. The number of $\mathrm{Cu} / \mathrm{Al}$ contact interfaces (diffusion paths), the different behavior of the molten pool induced by the difference in density of each composition [14], and the solidification rate acted in a complicated manner inside the welds.

Table 1 Measured chemical composition used EDX. The measured locations were marked in Fig. 5

\begin{tabular}{|c|c|c|c|}
\hline \multirow[t]{2}{*}{ Lap configuration } & \multirow[t]{2}{*}{ Measuring position } & \multicolumn{2}{|c|}{ Chemical composition (wt\%) } \\
\hline & & $\mathrm{Al}$ & $\mathrm{Cu}$ \\
\hline \multirow[t]{3}{*}{ ACA } & i & 30.3 & 69.7 \\
\hline & ii & 32.4 & 67.6 \\
\hline & iii & 34.2 & 65.8 \\
\hline \multirow[t]{3}{*}{ AAC } & iv & 92.8 & 7.8 \\
\hline & $v$ & 83.0 & 17.0 \\
\hline & vi & 6.7 & 92.3 \\
\hline \multirow[t]{3}{*}{ CAA } & vii & 16.2 & 83.8 \\
\hline & viii & 19.3 & 80.7 \\
\hline & ix & 100 & 0 \\
\hline
\end{tabular}

During the solidification process, a solution is formed via the stirring and diffusion of $\mathrm{Al}$ and $\mathrm{Cu}$ in the liquid state. The $\mathrm{Cu}$ content in the composition gradually decreased from the Cu-rich side to the Al-rich side, independent of the lap configuration. These results are in good agreement with the results of other literatures $[12,14,27]$. Zuo et al. [6] divided the IMPs of $\mathrm{Al} / \mathrm{Cu}$ into four zones, which could be distinguished by their morphology and chemical compositions; Zone 1 consisted of $\mathrm{Y}_{2}-\mathrm{Cu}_{9} \mathrm{Al} 4$ in the form of columnar grains. Zone 2 was a mixture of lumpish and net-like eutectic and hypoeutectic structures of $\mathrm{a}-\mathrm{Al}$ and $\theta-\mathrm{CuAl}_{2}$. Zone 3 consisted of a fine eutectic structure with $\mathrm{a}-\mathrm{Al}$ and $\theta$ phases. Zone 4 consisted of an a-Al dendritic structure near the Al layer. In this study, the shape and arrangement of 
zones were randomly formed because the laser welding speed was extremely fast and thus resulted in solute trapping during the rapid solidification process, as shown in Fig. 5.

\subsection{Effect of lap configuration on mechanical characteristics}

Higher hardness values were measured in the fusion zone than in the base materials due to the chemical reaction between $\mathrm{Al}$ and $\mathrm{Cu}$. The hardness of the base materials $\mathrm{Cu}$ and Al were $87.5 \mathrm{HV}$ and $47.6 \mathrm{HV}$, respectively, while the hardness of the welds was in the range of 45-649 HV. As shown in Fig. 6, a rapid change in the hardness was observed near the $\mathrm{Al}-\mathrm{Cu}$ interface, where intermetallic phases could be generated. The formation of intermetallic phases in the welds is promoted when a high heat input is applied to the specimen. The Cu diffusion distance of AAC was shorter than that of the other lap configurations because the diffusion path was only allowed to a faying interface. The hardness distribution was consistent with the composition distribution. Thus, it can be concluded that the lap configuration affected the hardness distribution of the welds.

The tensile-shear load also differed depending on the lap configuration and welding parameters (Fig. 7(a)). The tensile-shear loads tended to decrease in the AAC and CAA lap configurations as the interface width narrowed with an increase in the welding speed. However, in the ACA lap configuration, the tensileshear strength increased up to a welding speed of $350 \mathrm{~mm} / \mathrm{s}$ and then decreased. As a result of the tensile-shear test, an interfacial rupture occurred in all fabricated specimens regardless of the lap configuration (Fig. 8).

The failure loads of the T-peel test were lower than those of the tensile-shear loads in all cases (Fig. 7(b)). When the welding speed was $250-350 \mathrm{~mm} / \mathrm{s}$, the failure load with the CAA lap configuration was evaluated to be higher than that of the AAC or ACA lap configurations. In the CAA case, the hardness values at the interfacial joint between the second and third layers were maintained at a low value, as shown in the hardness profile (Fig. 6). Thus, it can be inferred that the failure was not affected by the formation of brittle IMPs in the CAA case. If the materials were consistent at the interface, the joint would have been more robust because the force was transferred by detouring the IMPs. Interfacial and pull-out mode fractures were also observed (Fig. 8).

\section{Conclusion}

This study investigated joint formation in multilayered laser welding subject to various process parameters. The results are as follows:

1. The penetration depth varied according to the lap configuration even under the same heat input condition due to the different laser power deliveries results from different beam absorption rates of Al and $\mathrm{Cu}$. In addition, the high heat capacity and thermal diffusivity of copper allowed the transferred energy to be easily dissipated to the surroundings.

2. The chemical composition distribution of the weld was affected by the lap configuration and the welding parameters. The forces induced by the recoil pressure are limited to stirring the molten pool, 
resulting in a non-uniform distribution of the layer components. The element distribution appears to be affected by the solidification rate, the number of $\mathrm{Cu} / \mathrm{Al}$ contact interfaces, and the position of the high-density material.

3. The tensile-shear and T-peel loads were affected by the lap configurations and welding parameters. The failure load of the T-peel specimens was lower than that of the tensile-shear specimens in all cases. The hardness distribution was consistent with the chemical composition distribution. Thus, designing joints to avoid stress concentration and the formation of brittle IMPs is essential to obtain desirable joint performance.

\section{Declarations}

Acknowledgements We acknowledge the financial \& technical support provided by the Korea Institute of Industrial Technology (EO-21-090).

Author contribution Joonghyeon Shin: conceptualization, methodology, writing. Minjung Kang: supervision review, data curation and editing, funding acquisition.

Availability of data and material No additional data available

Code availability Not applicable

Ethical approval No ethical approval was required for this research.

Consent to participate Not applicable.

Consent to publish All authors have read and agreed to the published version of the manuscript.

Competing interests The authors declare no competing interests.

\section{References}

[1] Chu S, Majumdar A (2012) Opportunities and challenges for a sustainable energy future. nature 488(294):1-13.

doi.org/10.1038/nature11475

[2] Das A, Li D, Williams D, Greenwood D (2018) Joining technologies for automotive battery systems manufacturing. World Electr Veh J 9(22): 1-13.

doi.org/10.3390/wevj9020022

[3] Lee SS, Kim TH, Hu SJ, Cai WW, Abell JA (2015) Analysis of weld formation in multilayer ultrasonic metal welding using high-speed images. J Manuf Sci Eng 137(3): 031016-1-8. 
[4] Lee WB, Bang KS, Jung SB (2005) Effects of intermetallic compound on the electrical and mechanical properties of friction welded $\mathrm{Cu} / \mathrm{Al}$ bimetallic joints during annealing. J Alloys Compd390: 212-219.

doi.org/10.1016/j.jallcom.2004.07.057

[5] Solchenbach T, Plapper P (2013) Mechanical characteristics of laser braze-welded aluminium-copper connections. Opt Laser Techno/ 54: 249-256.

doi.org/10.1016/j.optlastec.2013.06.003

[6] Zuo D, Hu S, Shen J, Xue Z (2014) Intermediate layer characterization and fracture behavior of laserwelded copper/aluminum metal joints. Mater Des 58: 357-362.

doi.org/10.1016/j.matdes.2014.02.004

[7] Schmalen P, Plapper P (2016) Evaluation of laser braze-welded dissimilar Al-Cu ioints. Phys Procedia 83: 506-514.

doi.org/10.1016/j.phpro.2016.08.052

[8] Xue Z, Hu S, Zuo D, Cai W, Lee D, Elijah KA (2013) Molten pool characterization of laser lap welded copper and aluminum. J Phys D Appl Phys 46 : 495501-1-9.

doi.org/10.1088/0022-3727/46/49/495501

[9] Schmalen P, Plapper P, Cai W (2016) Process robustness of laser braze-welded Al/Cu connectors. SAE Int J Altern Powertrains 5(1): 195-204.

doi.org/10.4271/2016-01-1198

[10] Zhou L, Li Z, Song X, Tan C, He Z, Huang Y, Feng J (2017) Influence of laser offset on laser weldingbrazing of Al/brass dissimilar alloys. J Alloys Compd 717: 78-92.

doi.org/10.1016/j.jallcom.2017.05.099

[11] Xiong J, Peng Y, Zhang H, Li J, Zhang F (2018) Microstructure and mechanical properties of Al-Cu joints diffusion-bonded with Ni or Ag interlayer. Vacuum 147: 187-193.

doi.org/10.1016/j.vacuum.2017.10.033

[12] Solchenbach T, Plapper P, Cai W (2014) Electrical performance of laser braze-welded aluminumcopper interconnects. J Manuf Processes 16 : 183-189.

doi.org/10.1016/j.jmapro.2013.12.002

[13] M. Braunovic (2017) Reliability of power connections. J Zhejiang Univ Sci A 8(3): 343-356. 
doi.org/10.1631/jzus.2007.A0343

[14] Lee SJ, Nakamura H, Kawahito Y, Katayama S (2014) Effect of welding speed on microstructural and mechanical properties of laser lap weld joints in dissimilar Al and Cu sheets. Sci Technol Weld Joining 19(2): 111-118.

doi.org/10.1179/1362171813Y.0000000168

[15] Kraetzsch M, Standfuss J, Klotzbach A, Kaspar J, Brenner B, Beyer E (2011) Laser beam welding with high-frequency beam oscillation: Welding of dissimilar materials with brilliant fiber lasers. Phy Procedia 12: $142-149$.

doi.org/10.2351/1.5062231

[16] Mai T, Spowage A (2004) Characterisation of dissimilar joints in laser welding of steel-kovar, copper-steel and copper-aluminium. Mater Sci Eng A 374: 224-233.

doi.org/10.1016/j.msea.2004.02.025

[17] Tan C, Jiang Z, Li L, Chen Y, Chen X (2013) Microstructural evolution and mechanical properties of dissimilar Al-Cu joints produced by friction stir welding. Mater Des 51: 466-473.

doi.org/10.1016/j.matdes.2013.04.056

[18] Sahin M (2010) Joining of aluminium and copper materials with friction welding. Int J Adv Manuf Technol 49: 527-534.

doi.org/10.1007/s00170-009-2443-7

[19] Abbasi M, Taheri AK, Salehi M (2001) Growth rate of intermetallic compounds in Al/Cu bimetal produced by cold roll welding process. J Alloys Compd 319: 233-241.

doi.org/10.1016/S0925-8388(01)00872-6

[20] Satpathy MP, Sahoo SK (2017) Mechanical performance and metallurgical characterization of ultrasonically welded dissimilar joints. J Manuf Processes 25: 443-451.

doi.org/10.1016/j.jmapro.2017.01.001

[21] Xi L, Banu M, Hu SJ, Cai W, Abell J (2017) Performance prediction for ultrasonically welded dissimilar materials joints. J Manuf Sci Eng 139(1): 011008-1-13.

doi.org/10.1115/1.4033692

[22] Das A, Masters I, Williams D (2019) Process robustness and strength analysis of multi-layered dissimilar joints using ultrasonic metal welding, Int J Adv Manuf Techno/ 101: 881-900. 
doi.org/10.1007/s00170-018-2936-3

[23] Luo Y, Chung H, Cai W, Rinker T, Hu S J, Kannatey-Asibu E, Abell J (2018) Joint formation in multilayered ultrasonic welding of Ni-coated $\mathrm{Cu}$ and the effect of preheating. J Manuf Sci Eng 140(11): 111003-1-10.

doi.org/10.1115/1.4040878

[24] Schmidt PA, Schmitz P, Zaeh MF (2016) Laser beam welding of electrical contacts for the application in stationary energy storage devices. J Laser App/ 28(2): 022423-1-6.

doi.org/10.2351/1.4943908

[25] Huang W, Wang H, Rinker T, Tan W (2020) Investigation of metal mixing in laser keyhole welding of dissimilar metals. Mater Des 195: 109056-1-14.

doi.org/10.1016/j.matdes.2020.109056

[26] Hummel M, Külkens M, Schöler C, Schulz W, Gillner A (2021) In situ X-ray tomography investigations on laser welding of copper with 515 and $1030 \mathrm{~nm}$ laser beam sources. J Manuf Processes 67: 170-176

doi.org/10.1016/j.maapro.2021.04.063

[27] Otten C, Reisgen U, Schmachtenberg M (2016) Electron beam welding of aluminum to copper: mechanical properties and their relation to microstructure. Weld World 60: 21-31.

doi.org/10.1007/s40194-015-0280-x

\section{Figures}




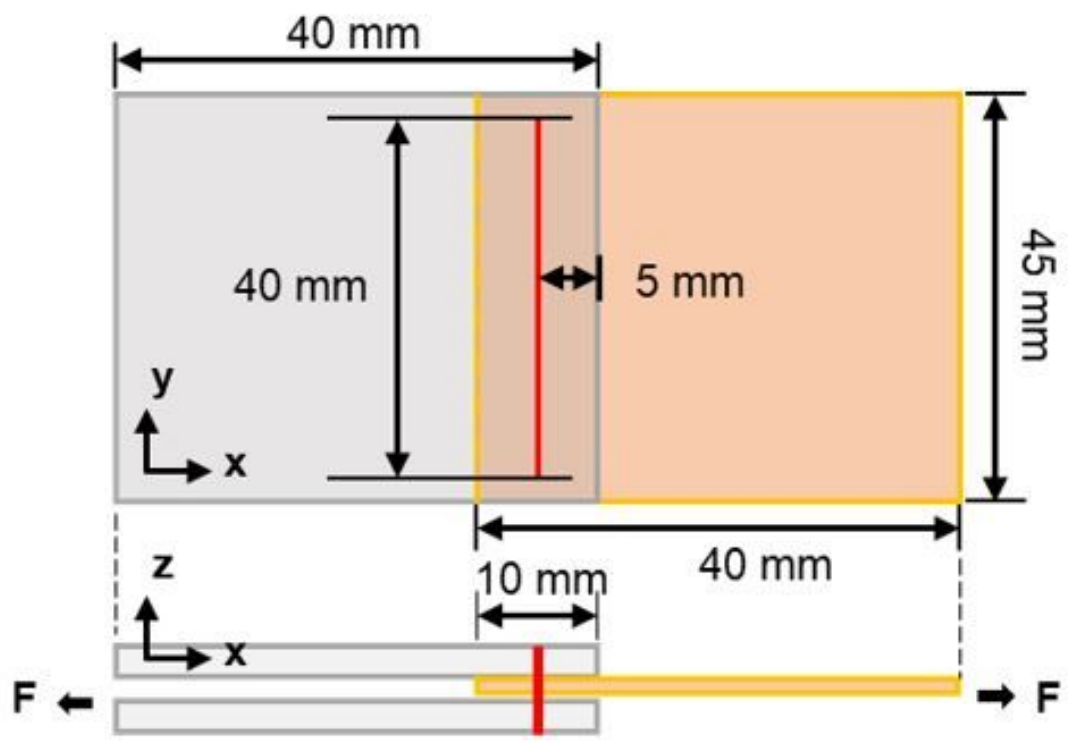

(a)

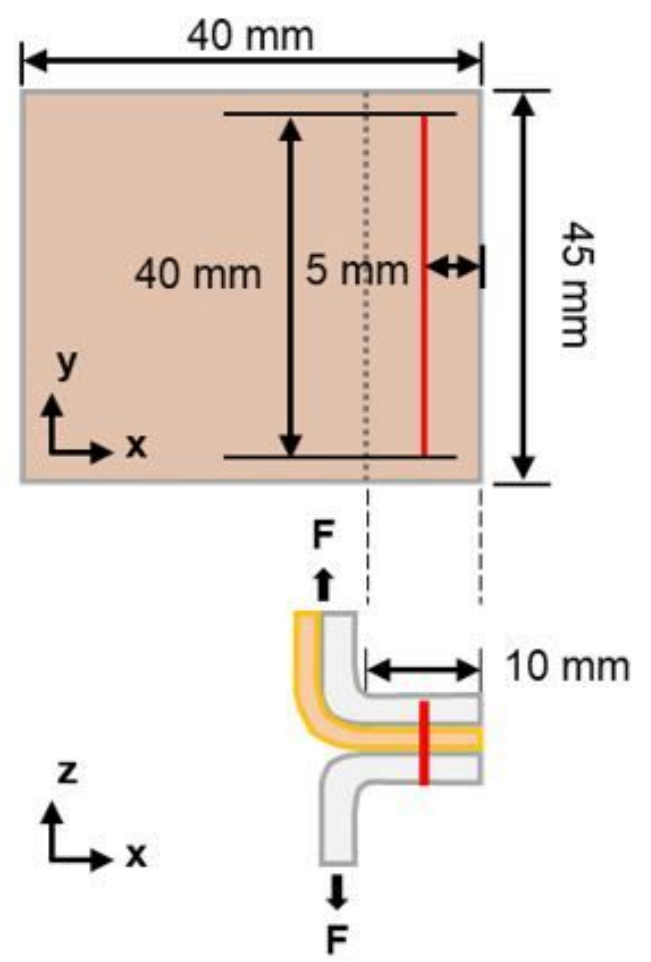

(b)

Figure 1

Schematic diagram of (a) tensile-shear and (b) T-peel specimens of ACA lap configuration 
Lap configuration

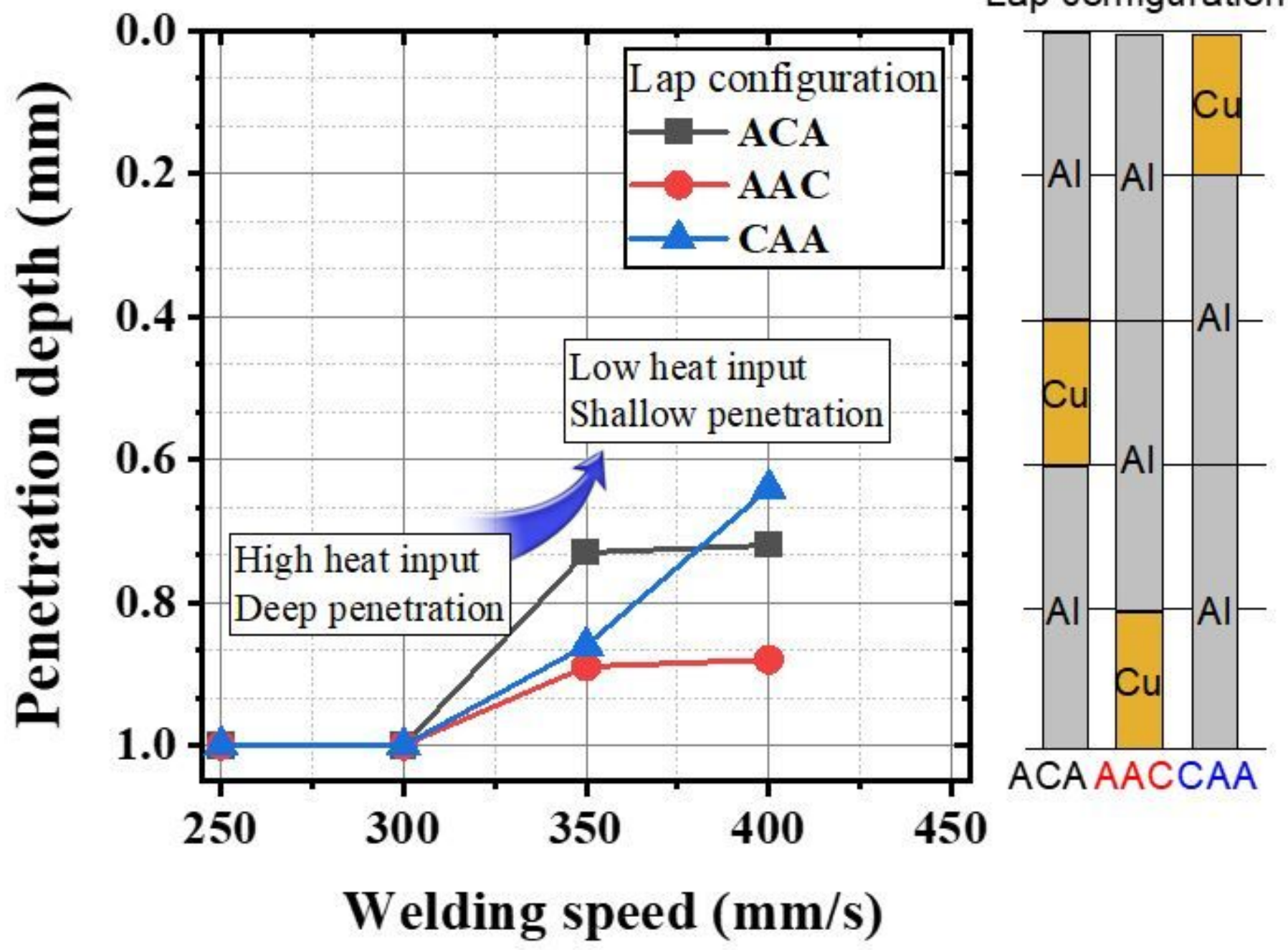

Figure 2

Penetration depth measurement according to the lap configuration and welding speed 


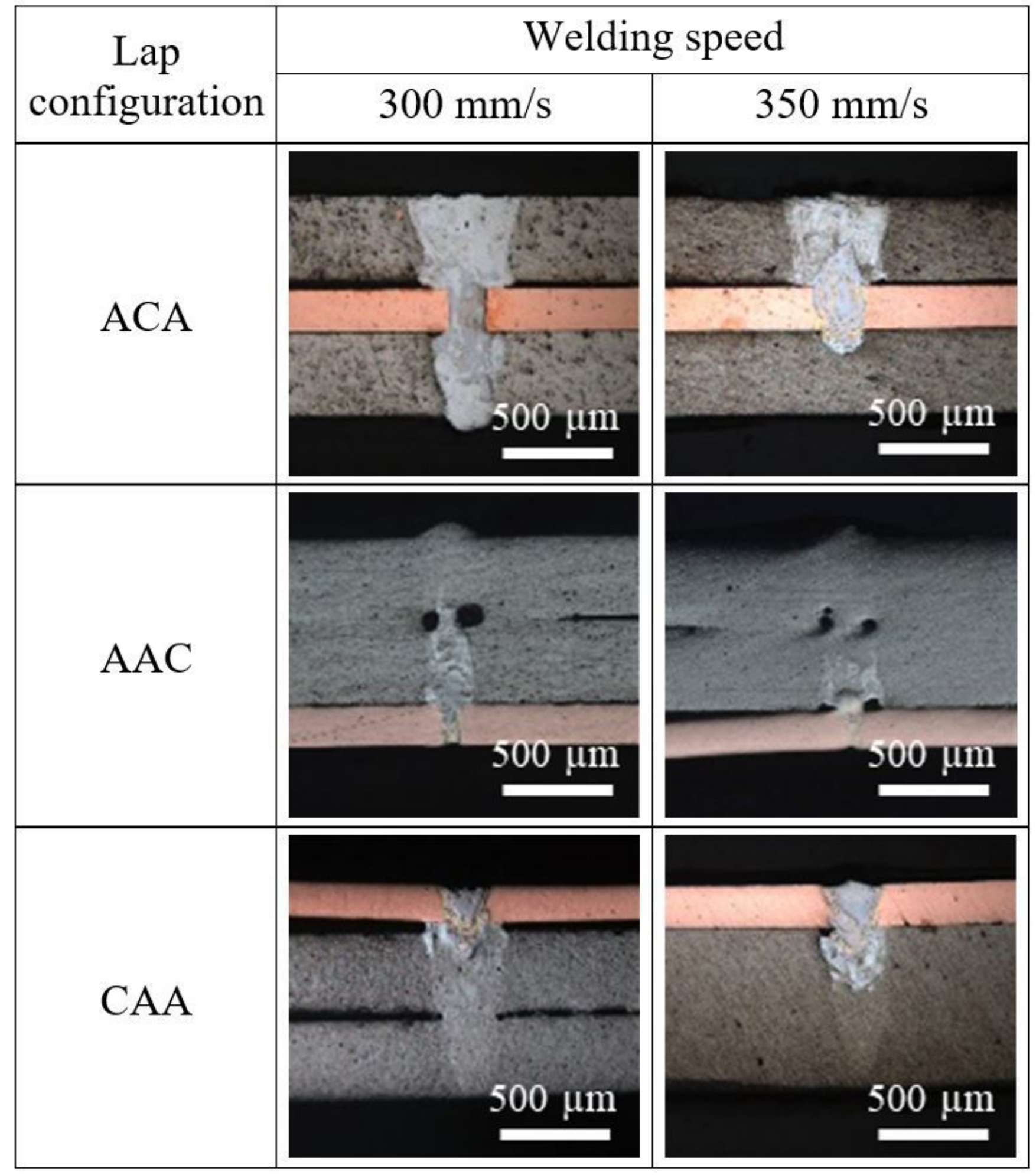

Figure 3

Macro-sectional images according to the lap configuration and welding speed 


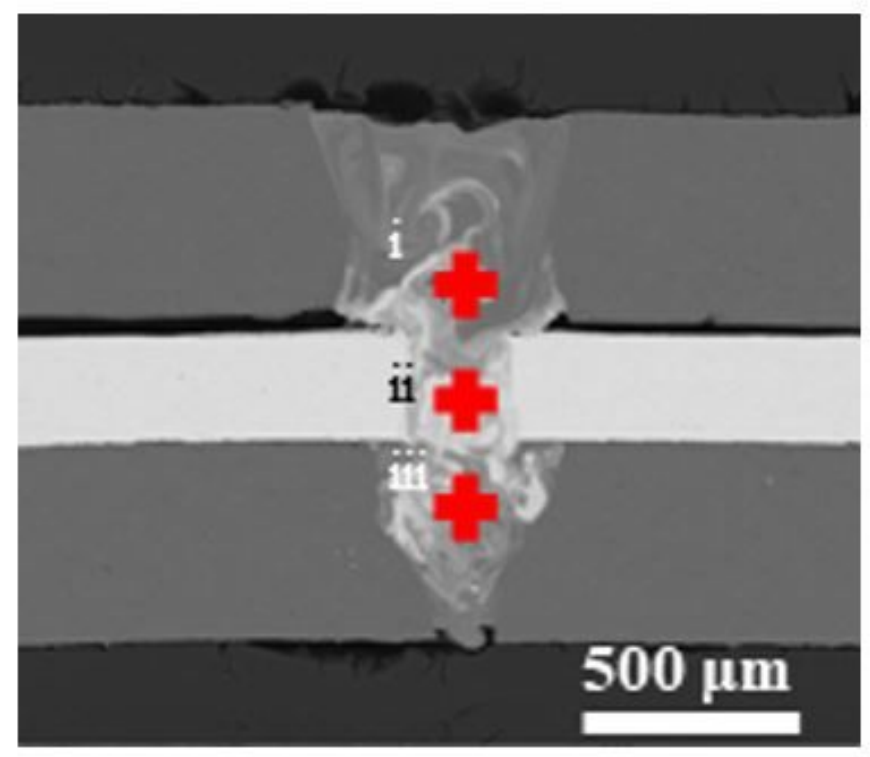

(a)

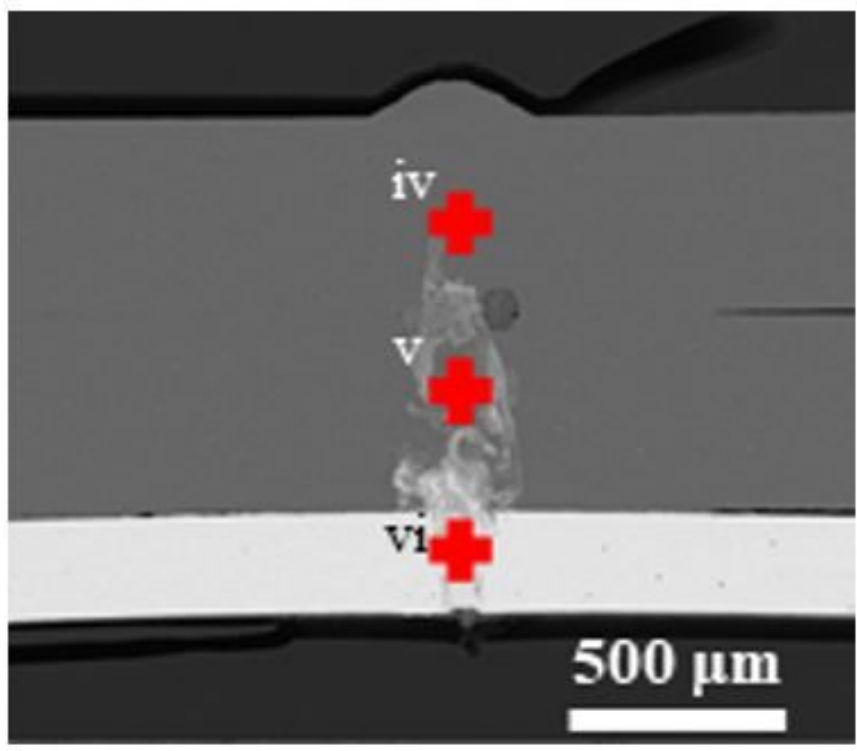

(b)

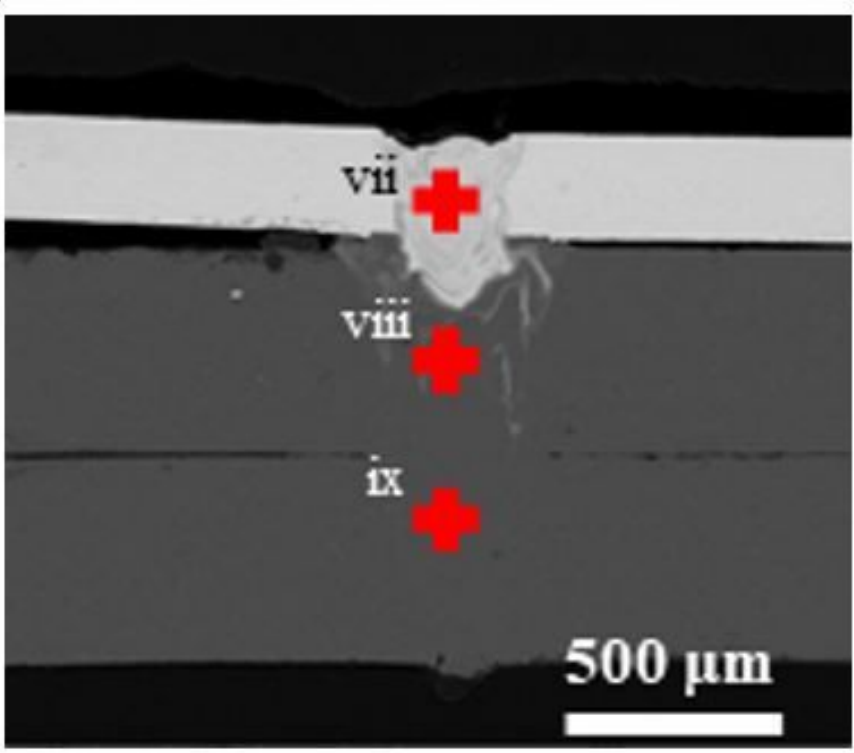

(c)

Figure 4

FE-SEM images of overlapped joint with various lap configuration under a welding speed of $300 \mathrm{~mm} / \mathrm{s}$; (a) ACA; (b) AAC; (c) CAA 


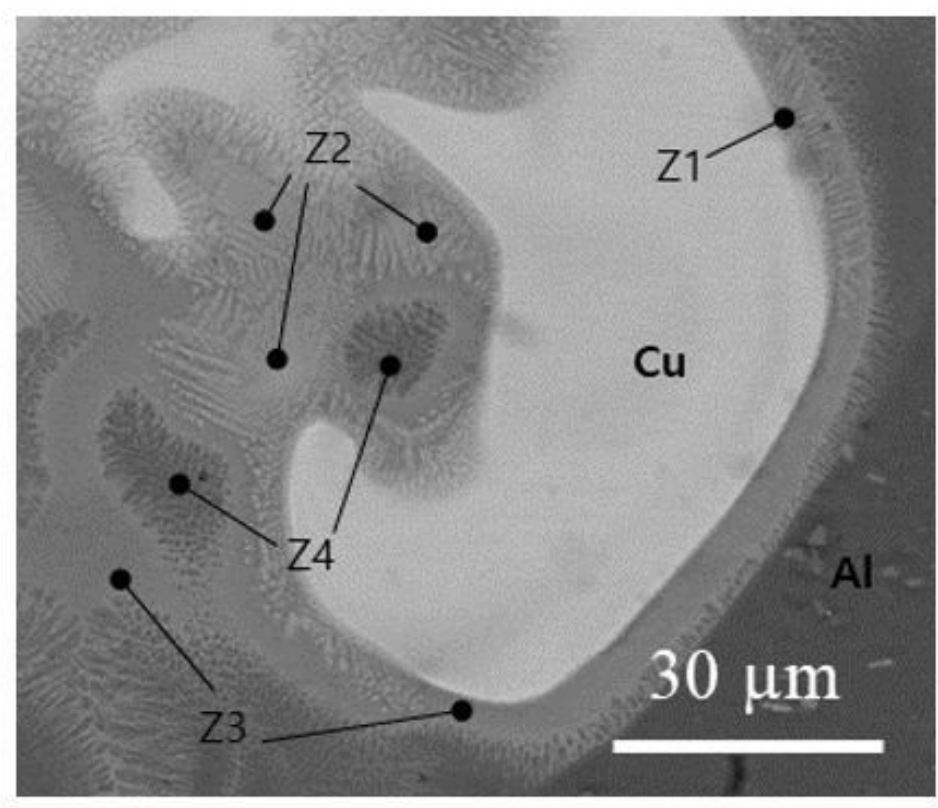

(a)

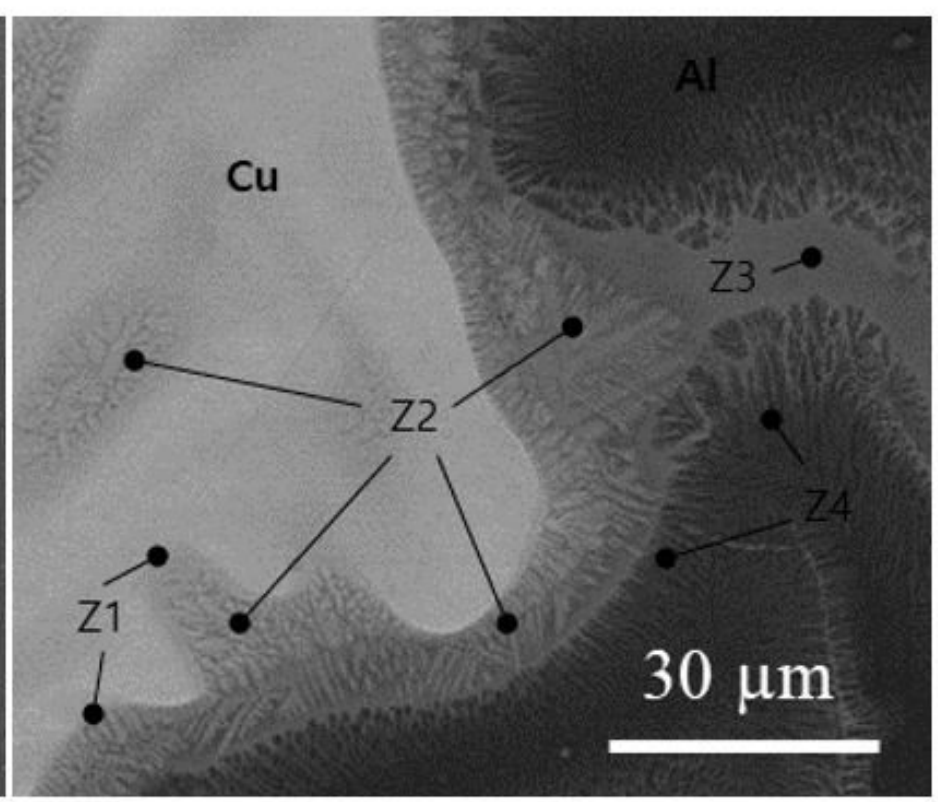

(b)

\section{Figure 5}

Morphology of intermetallic phases in (a) ACA and (b) AAC lap configurations 


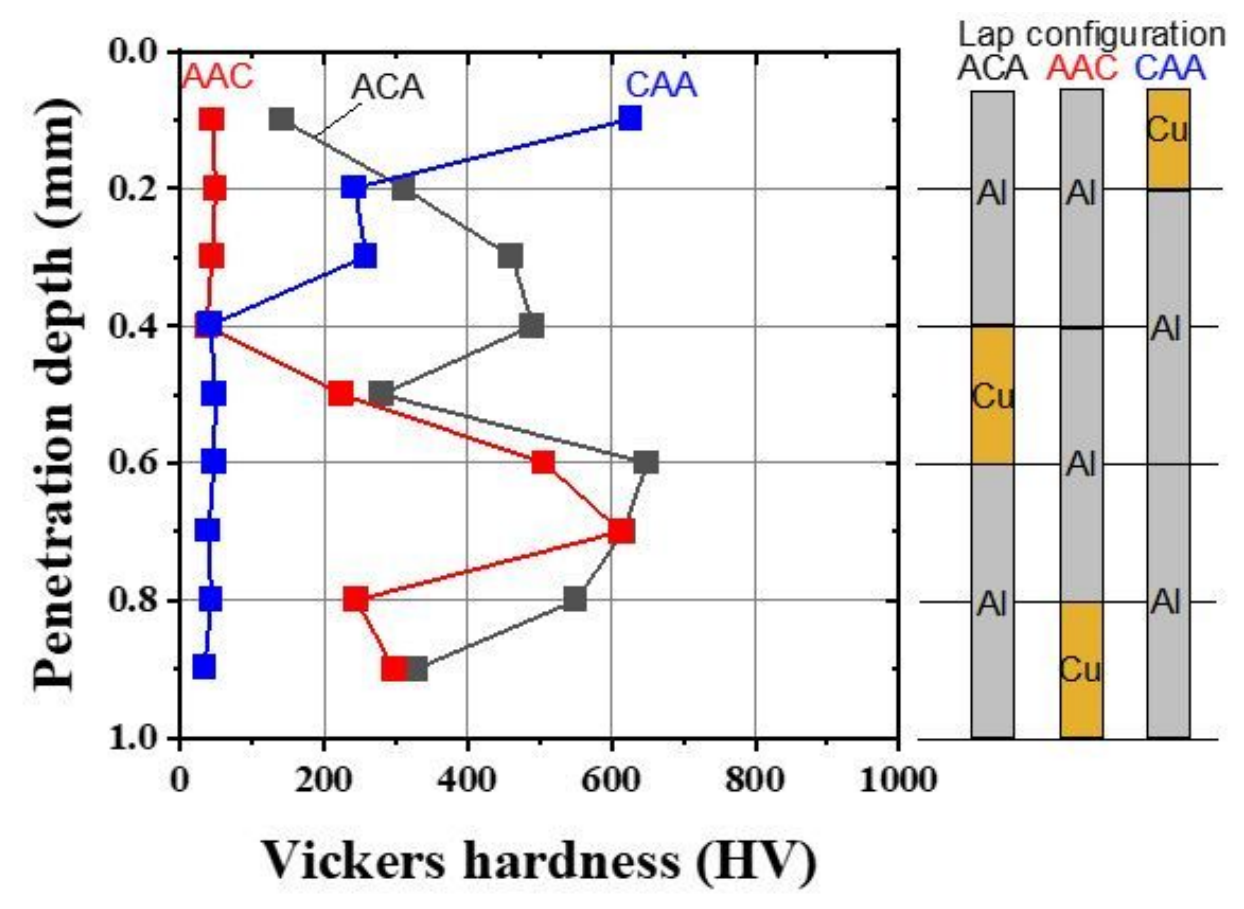

(a)

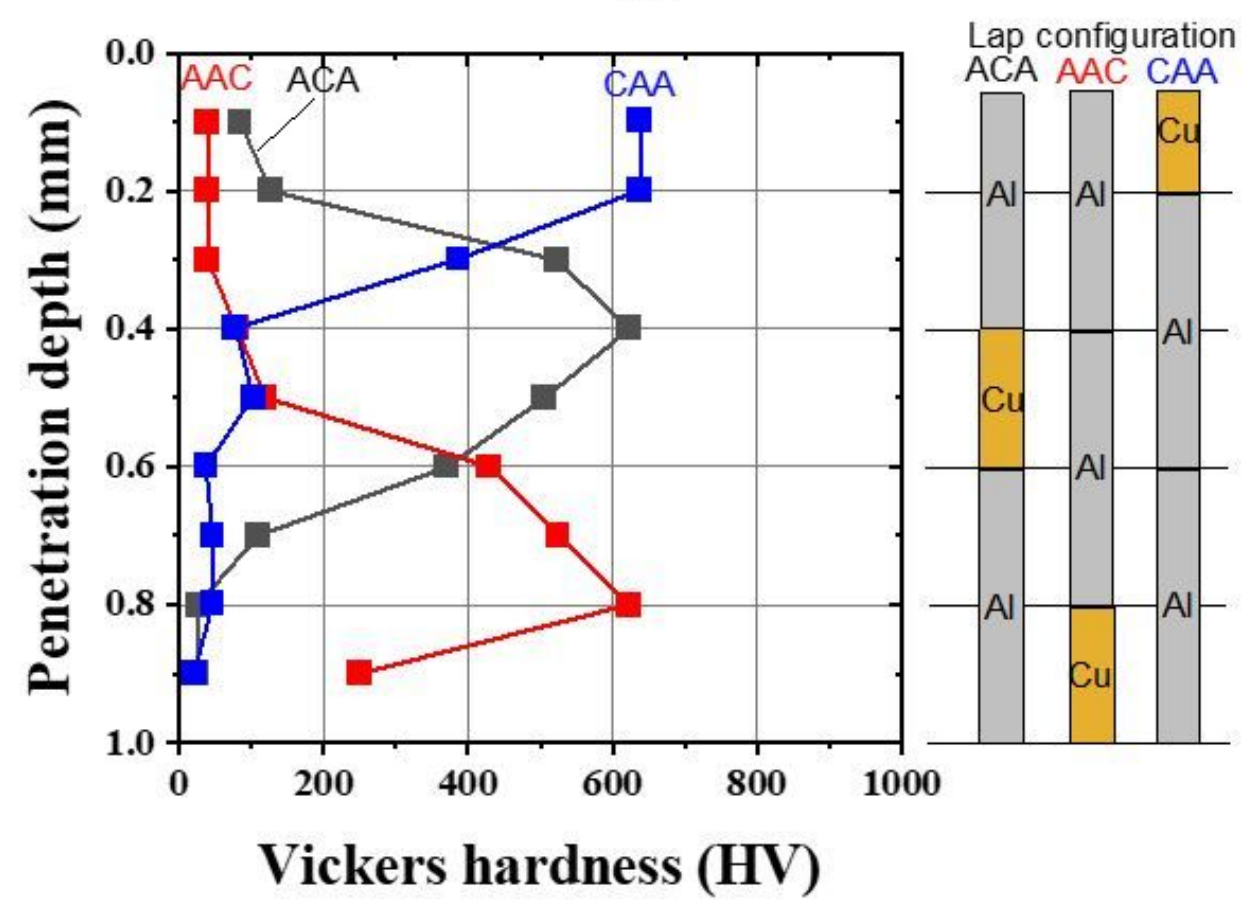

(b)

Figure 6

Hardness profile according to the lap configuration. The specimens were fabricated with welding speed of (a) 300 and (b) $350 \mathrm{~mm} / \mathrm{s}$ 


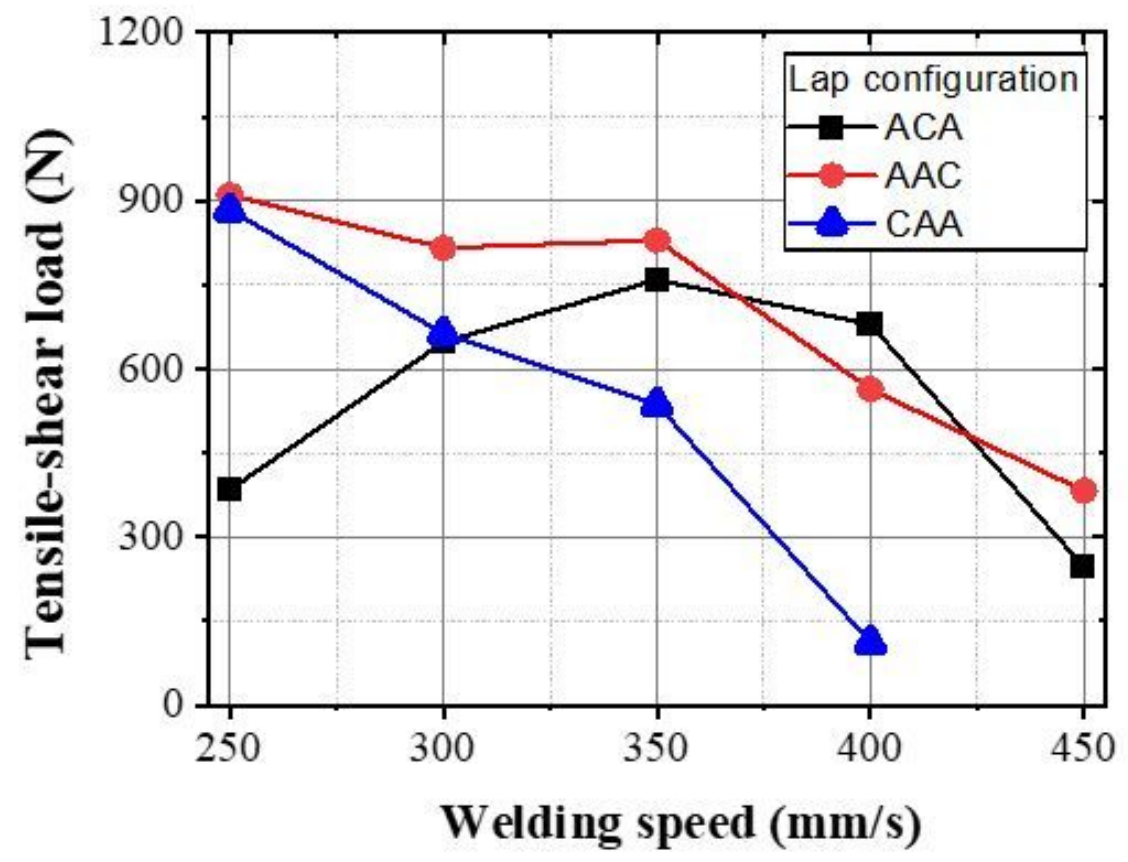

(a)

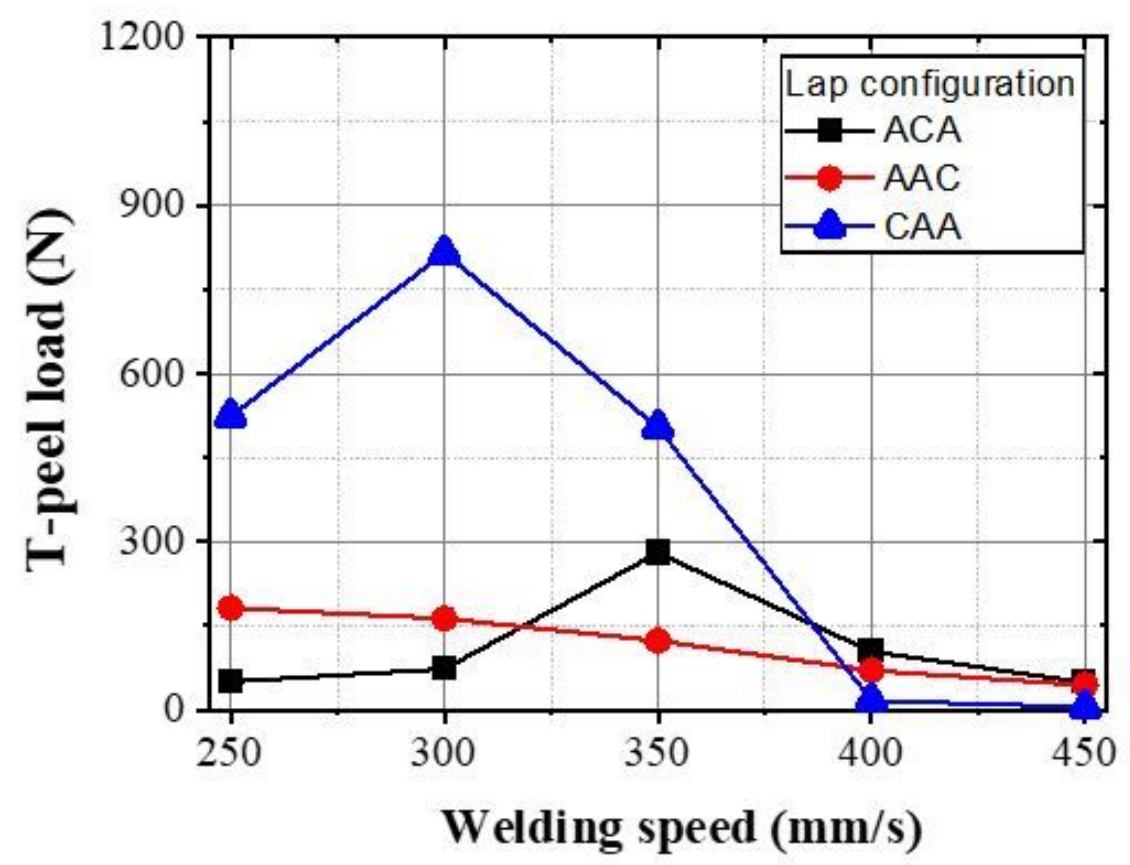

(b)

Figure 7

Measured tensile-shear and T-peel load depending on the lap configuration 


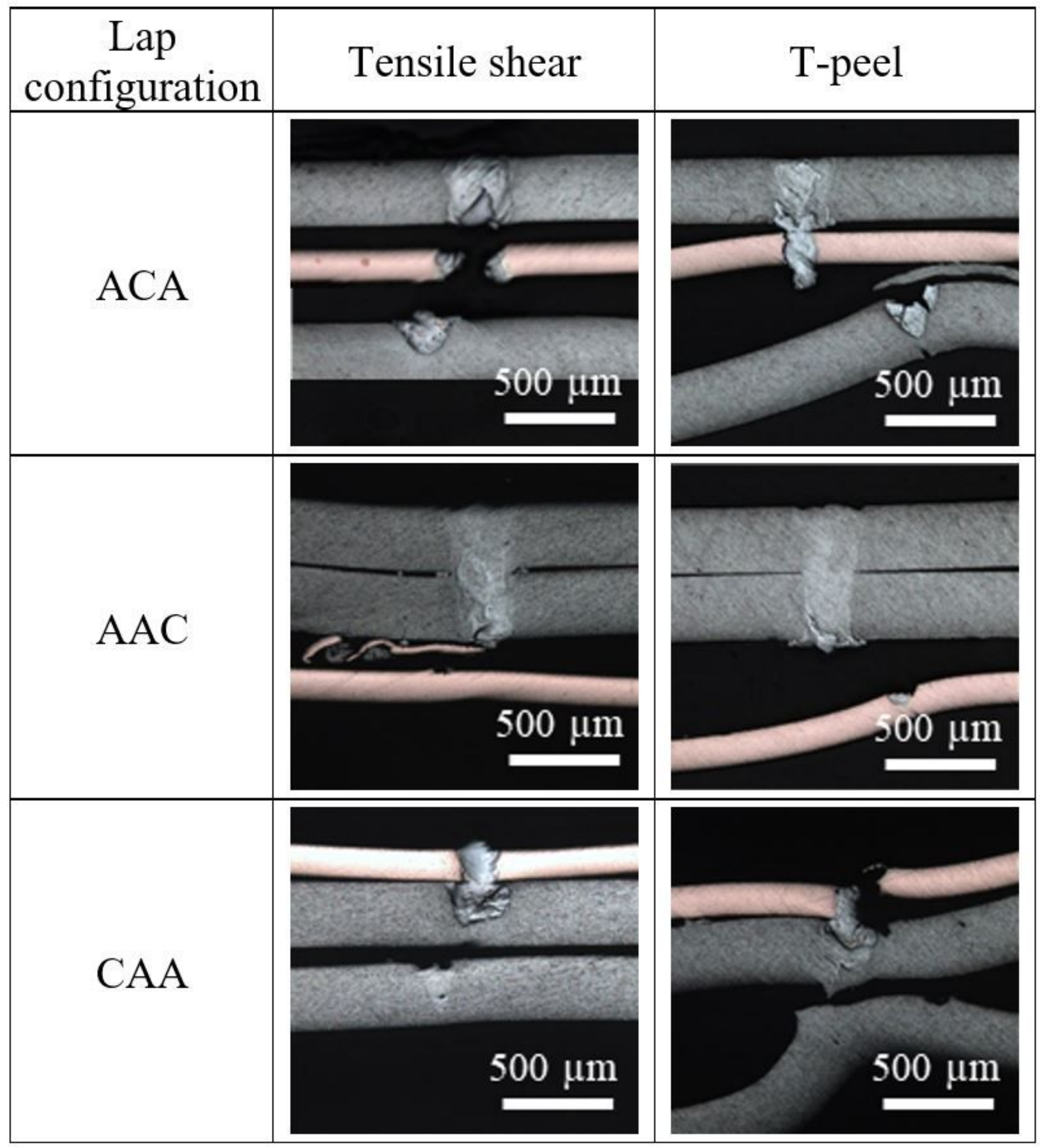

Figure 8

Macro-sectional images after tensile-shear and T-peel tests with differential lap configuration. The specimens were manufactured at a welding speed of $350 \mathrm{~mm} / \mathrm{s}$ 